\title{
Philosophy and Functional Structure of Medresetü'z-Zehra: A Study on Bediüzzaman Said Nursi
}

\author{
Kamaruzaman Yusoff \\ Faculty of Islamic Civilization, University Technology Malaysia, Malaysia \\ Corresponding author: Kamaruzaman Yusoff; Email: y.kamaruzaman@utm.my \\ Mansoureh Ebrahimi \\ Faculty of Islamic Civilization, University Technology Malaysia, Malaysia \\ Email: mansoureh@utm.my \\ Fatemeh Hamidifar \\ Faculty of Management, Islamic Azad University, Central Tehran Branch, Tehran, Iran \\ Email: fatimehh@gmail.com \\ Omer Yilmaz \\ History Department, The National University of Malaysia, Malaysia \\ Email:omeryilus@yahoo.com
}

Doi:10.5901/mjss.2016.v7n1s1p36

Abstract

Education has a dramatic role to give a platform to succeed as well as the knowledge to enhance the level of society in terms of several aspects. The values of education in an Islamic community will shine divinely over spiritual part of human beings. In Turkey, a leader, Bediüzzaman Said Nursi, was attempting in his whole life for stabilizing of his idea, Medresetü'z-Zehra. The aim of this study is to analyze Nursi's philosophy approach of his Medresetü'z-Zehra. It also elaborates the functional structure of Nursi's project. Indeed, it focuses on main representation of Nursi's Islamic, political, social and educational struggle especially in the pre-Republic era. Qualitative research method that employs empirical research approach has been applied to achieve the aim of this study. To him, this project was only the solution for the problems of bigotry, poverty and disunity among the Muslim community. He continued with his efforts to establish Medresetü'z-Zehra even in the post-Ottoman era, in spite of the many political obstacles he had to face.

Keywords: Medresetü'z-Zehra; The Tanzîmat; medrese; mekteb; tekke; zekât; Eastern Turkey

\section{Introduction}

Nursi's educational and political experiences put him in the different position of having to choose between education and politics (Yusoff, 2013). Since the political changes and oppressions did not allow him to move, he consequently chose the way of education in his efforts to lead the Muslim community. While he sought the support of politics for his educational projects during his Ottoman period; he was not given an opportunity by the Republican government to maintain his vision following the way of politics, although the deputies in the First Parliament, including many of the founders of Republic, supported him. Because of this, he decided to concentrate on individual informal education rather than governmental formal education (Awang, 2015).

Nursi first appeared in Istanbul in his Ottoman Kurdish image to solve the educational problems of Kurdish society to which he belonged. His visit coincided with the most complicated period in which the state was between life and death. This made him concerned about the survival of the Ottoman State. Its survival was only possible through high quality education. To be of good quality, education had been holistic, integrating religion and modern science. From this point of view, he wanted to implement his Medresetü'z-Zehra project in Eastern Turkey. Afterwards, his vision included all the Ottoman territories. This required him to discard his Kurdish identity and assume only the Ottoman identity. 


\section{A Philosophical Approach to Nursi's Medresetü'z-Zehra Project}

The Tanzimat Reforms marked the beginning the process erosion of the physical and spiritual foundations of the Ottoman Empire, which led to the current problems today's Turkish society is facing. After the Tanzîmat, various political, literary and philosophical trends were introduced in the Ottoman State (Bolay, 1995). By opening the new European style schools, the philosophical and literary movements such as materialism, positivism, Darwinism, naturalism, Romanticism and atheism partially gained acceptance by some intellectuals. These movements had effects in the educational, albeit implicitly before 1908. By declaration of freedom in that year, those movements were empowered and supported by the media which was now free from restrictions. With this power, antipathy and opposition to religion became common. Those movements became more vocal and effective towards the 1920's and continued up to the declaration of Republic in 1923. It was this antipathy caused and facilitated the removal of all religious symbols and establishments, including medreses. The years from 1908 to 1923 were the period when the Ottomans both psychologically and spiritually tortured, capitalising upon the administrative weaknesses of the Ottomans after Sultan Abdülhamid II (Mim Kemal Öke, 1993).

Considering that situation, Nursi believed that his Medresetü'z-Zehra was only kind of educational establishment which would help to solve the problems mentioned above. Since backwardness of Muslims had started from the educational system, Nursi aimed to protect society against the unseen dangers such as ignorance, disunity and poverty. According to Nursi, his project was important for people to understand the true spirit of nationalism. He divided nationalism into two aspects, which are positive and negative nationalism. Negative nationalism takes nationality as an essential and puts it before Islam. This kind of nationalism builds everything on nationality and places the sacred matters in the service of nationality. As for positive nationalism, it means people knowing each other, just as Islam taught, and it puts nationality in the service of Islam. The essence of positive nationalism is Islamic nationalism. In Nursi's discussion of the harms of negative nationalism, he cited the example of one of his Kurdish students who was mistreated by his Turkish nationalist teachers while studying in Istanbul. The teachers inadvertently incited the spirit of Kurdish nationalism in the student. The same student formerly used to love the Turks for having served Islam through the lesson of positive nationalism that he had learned from Nursi himself. He, as a matter of fact, used to prefer a pious Turk to a reprobate Kurd. After talking with him upon his return from Istanbul, Nursi realized that his student had been diverted from the right path. It took a number of lessons to bring him back to the right course. In 1950's, Nursi mentioned this anecdote in a letter he wrote on his project of Medresetü'z-Zehra to the Prime Minister and the President of the time.

Although Nursi was a Kurd and he had lived among the Kurds, he did not join or support any Kurdish nationalist organization or nationalist movement (Akgündüz, 1997, 1999). He defended Islamic nationalism instead of tribal or racial nationalism. Moreover, he respected the Turkish nation and army because they had been the standard-bearers of Islam for around a thousand years since the time of the Abbasids. According to Nursi, the best to prevent the spread of anarchist movements in the East was his project of Medresetü'z-Zehra. It is a fact in human history that most of the prophets appeared in the East, while the philosophers appeared in the West. This may imply that what makes the people of Eastern Turkey happy are religion and spirituality. All other projects and works would be useless in the East as long as they disregarded religion and spiritual values. Unfortunately, most of the rulers thought that the problem of the East was the lack of economic and structural development.

Nursi believed that Medresetü'z-Zehra would make a major contribution to Islamic nationalism, which, to him, was the only positive nationalism. According to him, the Eastern part of Turkey lied at the centre of the Islamic world. Countries like Iran, India, Arabia, and Caucasia would gladly and quite easily send their students to the university which would be located in that area. At the same time, these students from overseas would easily go along with the Turkish and Kurdish students. In this way, the students from different nationalities would get to know each other, enhance the spirit of Islamic nationalism, and be saved from the dangers of negative nationalism. Otherwise, when Muslims only learn philosophies which do not recognize Islam, members of each nation gets deceived to only love their compatriots while hating all others.

During the Ottoman period, although the ethnic identity of the Arabs, Kurds and the other nations which were the members of the Ottoman State were duly organized, they all accepted that they were subjects of the Ottoman Empire. Likewise, while Nursi was an Ottoman citizen, he used the name Sa'id-i Kurdi since there was no rule against that. During Turkey Republic he could not identify himself with his ethnicity, hence changing his title to the name of his village (Akgündüz, 1993), to avoid conflict with the Turkish nationalism. Nursi's concept of Medresetü'z-Zehra had begun with the purpose of solving the problems of Kurdish society. He wished to help the Kurds to conform to the demands of the modern world. Western Turkey was apparently more prepared for the new educational system coming from Europe than Eastern Turkey. People of Eastern Turkey found it difficult to accept this modern educational system. According to Nursi, Eastern people still bore the 1516 Kurdish character as a result of which then had become dependent on Yavuz Sultan 
Selim the first Caliph of the Ottomans (Nursi, 2003). Practising the modern educational system in the East could have caused bigger problems afterwards. He clearly anticipated the turmoil that happened later and the terrorist reactions demanding the so-called Kurdish independence which started in 1970's and continued till the present. All this can be attributed to the government's failure to implement Nursi's Medresetü'z-Zehra project in the East. Had it materialized, there would be no way terrorism could exist in that area (Badıllı, 2005). Unfortunately these problems have proven that Nursi was right. It is quite remarkable that since the Kurds became dependents of the Ottomans, they had never caused any difficulty during their at least three hundred years (since 1516) of living under the Ottoman Empire (Akgündüz, 1997).

Nursi wanted to use Medresetü'z-Zehra as the means to unify the Muslim nation. He wanted to bring together the institutions of medrese, mekteb, and even tekke under the same roof. This would start dialogues and make the Ottoman nation progressive from three directions. This progress would eventually be translated into greater Islamic unity, thereby giving hope to the other Islamic nations. The foundation of the unity would be laid with students' coming to study in Medresetü'z-Zehra from all the Islamic countries (Kırkıncl, 2004). As he mentioned afterwards in his Risâle-i Nur, Medresetü'z-Zehra would also be an opportunity to disseminate the message of Islam to the world through the dialogues with some of the religious Christians who would be welcome to join these activities. Moreover, Nursi intended to make peace between the European civilization and the religion and civilization of Islam. After all, remarks Nursi, the Qur'an does not prohibit Muslims from admiring the civilization and progress of Europe, or from acquiring whatever is good in their civilization (Michel, 2005). In this way, the world would move closer towards peace by understanding the reality of Islam through Medresetü'z-Zehra. This was truly a great idea. But be implemented in reality, it had the first be understood and accepted by the Muslims. Unfortunately, Muslims then were not yet ready for these forward-looking ideas.

From the standpoint of the concept of cihad in Islam, Nursi realized the importance of concentrating on the spiritual dimension of cihad rather than on the physical dimension. This spiritual dimension was to demonstrate the miraculousness of the Qur'an through Medresetü'z-Zehra (Al-Kettani, 1995). From the earliest days of Islam, the enemies of the Qur'an had always failed to attack the truths of the Qur'an in a logical way. This made them to resort to using sword against Muslims. In response, Nursi equipped himself with knowledge of science and philosophy as a means to counter their attack. He invited people to wage cihad against their own souls, which was the greatest cihad, as the Prophet Muhammad (PBUH) had taught. Before embarking this cihad, the doubts about the Qur'an had to be removed from people's minds. This marks starting point of Medresetü'z-Zehra, an institution planned to gather Muslims around the Qur'an. In this plan, he aimed to turn science and philosophy, which were used by the infidels in their attacks against the Qur'an, into a shield to protect the Qur'an. In essence, the concept of cihad does not mean only fighting with the arms but it also consisted of various broad meanings. For instance, before the Hijrah from Mecca to Medina, the order for cihad that was revealed in Mecca could not have meant a physical cihad (Al-Qur'an: Furqan 25:52; Vahide, 1995 ). In the Old Sa'id period, while Nursi did his cihad through the way of persuasion together with the dream of Medresetü'z-Zehra, he had already performed his duty of physical cihad against the infidels in the First World War. During the Republic time, although Nursi generally advised his students not to go into military service, thereby abandoning their spiritual cihad, he sent one of his students to Korea to fight against communism.

One of the main reasons that motivated Nursi to propose the project of Medresetü'z-Zehra was that the medreses were losing their main purpose. Moreover, they had failed to publicize themselves and to adequately deal with the positive sciences. On the other hand, mekteb's being in distance religion-based education. Other reasons included disunity, tricks played on Muslims, their despair, unconscious westernization, racism, as well as the rise of the West which now controlled all financial and physical resources (Yetim, 1998). Since the instrumental studies such as logic, Arabic grammar and syntax had become superior and given priority in medrese curricula, the higher sacred studies such as Qur'anic exegesis (tefsir), Hadith, theology (kalâm), were left without enough allocated time (Yetim, 1998). The mekteb, which provided instruction in the modern sciences that had been omitted by the medrese, left out the Islamic sciences. Thus an excess in the medrese itself caused a deficiency in mekteb. It was at this time that, Nursi tried to attract people's attention to the Qur'an and its educational style which involves the integration of religion and science (Nursi, 1996). Nursi argued against the ignorance of modern sciences in medreses, in his work titled Muhâkemât (Nursi, 1996). One of the reasons which made the medreses' reject the innovations was that those who accepted innovations were generally opposed to the religious teachings (Nursi, 1996). Still, argued Nursi, even if one is a disbeliever, it does not mean that all his attributes are bad. For instance, Europeans had some good characteristics acquired from the true Christianity which were acceptable in Islam. To Nursi, the issue medreses was matter of life and death.

Nursi evaluated Medresetü'z-Zehra as a door which would open to the innovations and modern sciences. The same door could also be used by Europe to understand the true aspect of Islam. Eventually, this would lead to the progress of the world. It represented a double-sided response to globalization: one side representing the physical sciences and the other reflecting the spiritual sciences. Nursi had already mentioned that effort of the student would take 
flight on these two wings. According to Nursi, studying only the narrative religious sciences and opposing the truths proved by positive sciences would cause harm to the essence of Islam and could adversely affect the worldly progress of a country (KırkıncI, 2004). However, the first separation of the religious and the positive sciences appeared during the reign of Sultan Abdülmecid. Mustafa Reşid Paşa, who had been ambassador to Europe and who was imposed on the Sultan as grand vizier, had the positive sciences removed from medreses under the influence of the British (KırkıncI, 2004). Nursi claimed that each field of sciences is a sign to prove the reality of God and the other truths of belief. These signs remove the doubts in the minds against the truths of belief. When one acquires the sciences, the hidden truths of the Qur'an gradually appear one by one. Thus, Nursi held that although time grows older, the Qur'an grows younger and its signs become clearer (Nursi, 1997).

Nursi's project was quite appropriate to human nature. Human beings have both physical and spiritual aspects. Spiritual systems include the spirit, consciousness, conscience, understanding, the mind and the like which are all necessary to maintain and develop his physical existence. Spiritual values, which help to keep the entity and integrity of a society, include language, religion, culture, history, accumulated experiences, and so on. Nursi especially mentioned that a godless nation would not be able to survive. By this he was referring to communist Russia. He even pointed out that Russia would disintegrate one day (Light, 2002). According to Nursi, education is supposed to satisfy the two aspects of individuals. Albert Einstein, the famous physician, agreed with Nursi when he argued that religion without science is lame and science without religion, blind (Şen, 1985). The physical and spiritual aspects of man cannot be separated. If the human body is taken to be a miniature or microcosm of human society, the social fabric of society cannot be thought to be maintained without spiritual religious sciences which are equivalent to the heart together with the positive sciences which are equivalent to the mind. Nursi compared the relationship between science and religion with the relationship between the white part of the eye and the black part of the eye (Nursi, 1998). While science represents the white part, religion represents the black part. The positive science, which seems attractive in appearance because of the whiteness, is not able to see around without the religious science which seems unattractive. Although it is black, in fact, the one which sees.

Nursi tried to reconcile between religion and philosophy as he did between religion and science. According to him, the separation of religion and science was as dangerous as the separation of religion and philosophy. Actually the questions handled by philosophy are the same questions handled by religion. It is only that religion gives definite answers to these questions while philosophy gives no answers. The answers that philosophy gives necessitate deeper questions, which lead us to a paradox whereby we will never find the answers in minds. Irreligious philosophy is a sophistry and a scorning to the universe (Nursi, 1998). Thus in the planned Medresetü'z-Zehra, philosophy was intended to be studied together with religion and science (Bolay, 1995). The point to be noticed here is that religion was supposed to be in the position of a leader, and science and philosophy to serve it (Nursi, 1998).

Nursi advanced the concept that religious belief is not only a science but also the most important of all sciences. Previously, the ulema had failed to recognize that religious belief is a science. They only accepted hadith, kelâm and fikı as sciences (Açוkgenç, 1995). In addition to these, Nursi claimed that true belief encompassed all sciences and truly studying science strengthened belief. A person's belief in God gains strength when he studies the scientific realities of things which God created in the universe. Another concept that Nursi emphasized was that the universe is a book of Divine signs which we should be able to read. According to Nursi, the pen writing that book is the atoms, and the ink, ether. The spiritual eye, which is capable to read that book, is belief in the hearts. However, according to him, the physical eyes on their own are blind to the spiritual realities of the universe. While Islam did not reject science, it cannot be confined to the limited discoveries of science (Mim Kemal Öke, 1995). Science is simply the process whereby humans discover the hidden knowledge, which is an endless power created by the Possessor of infinite knowledge. As the universe is believed to be created by God in the Islamic faith, and since science deals with this universe, it has to be a manifestation of the treasures of Divine knowledge. Hence, it is impossible to set limits for science. Islam cannot be considered as setting limits for science when it claims that science belongs to the Possessor of infinite knowledge, and that all creation belongs to the Possessor of infinite power. On the contrary, it propels science forward to make discoveries. According to Nursi, scientific discoveries have to be considered as signs of the infinite knowledge of the Creator. Otherwise science would be a veil over the eyes of man preventing him from being saved from the clutches of materialism. A purely materialistic approach to science could increases our ignorance of the real wisdom behind material beings and is contrary to the ethics of science.

Starting with the above explanation, Nursi introduced a new approach to the miracles of the prophets (PUT). According to him, the miracles of the prophets (PUT), which confounded their contemporaries, were the peak point that the science would be able to reach at that time. For instance, the staff of Moses (PUH) was considered to be the most advanced technology for bringing water out of the ground. Likewise, the body of Prophet Abraham (PUH) was not burned 
when he was thrown into the fire, encouraging people to discover fireproof garments. In this way, in his treatise (Nursi, 1998), which called attention of people to science, Nursi explained the message of the Qur'an, making a point to make a scientific conclusion for each miracle. He called attention by saying that "Come on! You also work and you can also discover something by getting inspired from those miracles!" With this integrated spiritual and scientific education in Medresetü'z-Zehra, he hoped that the dispute between medrese and mekteb would be solved.

\section{Functional Structure of Medresetü'z-Zehra}

Nursi aimed to eradicate the social problems of Eastern Turkey, exposed which the future of the Eastern people and the entire Turkish society to great danger. In his Münâzarat, written in 1911, based on his lectures to the tribes of the East, he pointed out the key issues. These included: the suitable name of the establishment, languages to be taught, qualifications of teachers and students, the nature of the local people, the issue of specializations and divisions, professional courses, teacher training, unity of education, how to generate income for the establishment, etc. He concentrated on these basic matters, leaving the government to provide the physical structure of the establishment according to situation and the time. At the beginning, Nursi's plan was for a high school level establishment rather than a university. This would be of equal status as the more famous official high schools like the Mülkiye (the School of Political Science), Tibbiye (the School of Medical Science), than Dâru'l-Fünûn university of Istanbul which was established in 1900 but only developed well at the time of $2^{\text {nd }}$ Constitutional Monarchy (Alparslan, 1999). For the school to be equal in status with the best schools in the country, its examinations would have to be administered by the government based on the rules of the high schools' examinations. Graduation requirements would have to be on par with those of the best schools.

Nursi laid down conditions to ensure that Medresetü'z-Zehra would function efficiently. Firstly, the establishment should bear the name medrese as the people of the East were more interested in medrese which was popular and held in high esteem among them. With the influence of medrese ulema and the people of medrese in the East, there was a negative reaction to the name of mekteb and similar new names. These were suspected of undermining religion through promoting social and material innovations. Nursi did not want the government to arouse the negative reactions of the public. Understanding the importance of knowing psychology of the people (Mürsel, 1995), he suggested through this action that the nature of the local people should be taken into consideration instead of trying to impose things on them. Education in the Medresetü'z-Zehra was supposed to be in tri-lingual. Learning the Arabic language would be compulsory, Turkish necessary, and Kurdish optional in Medresetü'z-Zehra. This was in view of the fact that the school would be located Eastern territories of the Ottoman State which consisted mostly of Kurdish people. Kurdish was their local language, Arabic the language of science and communication, and Turkish the official and political language. Before that, only Arabic had been the official medrese language from the time the medreses were first established. Nursi's intention to increase the number of the languages from one to three was a bold new step.

He recognized that to be successful, Medresetü'z-Zehra, would have to give consideration to the languages spoken by the local people. Nursi offered Kurdish to be an optional local language in Medresetü'z-Zehra, so that local students would be taught in the language they could understand. This would eventually help to eradicate ignorance and negative nationalism from Eastern Anatolia. Arabic language, which had already been integrated with the culture and the local language of the area through medreses, would be compulsory to save the culture and the religion. Since the official language of the Ottoman State was Turkish, the necessity of studying it is self-evident. Turkish was the most widely spoken language among Muslims, especially in the regions of Iran, Turkistan, and Caucasia and the neighboring areas. Turkish language was supposed to be known by all students enrolled in Medresetü'z-Zehra from Arabia, India, Iran and Caucasia. From the $19^{\text {th }}$ century onwards, with the efforts of Gaspiralı İsmail Bey, Turkish functioned as the main communication, political and cultural language in a wide region, especially in the regions occupied by Russia and China, besides its being the official language in the Ottoman State (Alparslan, 1999).

The teachers of the Medresetü'z-Zehra would be expected to know both the religious and positive sciences to be able to teach the real wisdoms of the actions in the universe through the religious knowledge. In fact, the teachers of each branch would be required to know, at least all the common religious matters. These would support and strengthen their attempts to explain the mysteries of the scientific actions in each branch. Initially, the Teachers' Mekteb (Daru'lMuallimîn) was supposed to be temporarily attached to Medresetü'z-Zehra to facilitate the exchange between the order and intellectual fertility of the mekteb and the virtue and religious devotion of medrese. They would share their experiences and knowledge in a way that would help the teachers of mekteb and medrese to acquire integrated religious and positive sciences, which they would then propagate in their respective institutions. At the same time, the teachers were supposed to be either from among the Kurds trusted by both the Kurds and the Turks, or among those who had a good mastery of the local language to ensure that they would be able to interact with the local community in and around 
Medresetü'z-Zehra. The teachers had to take into account the capacity and cultural level of the community they were to serve. Thus only the graduates of the medreses in other regions who knew the region's local language or who were familiar with it would be appointed as teachers.

The nature of the local people had to be taken into consideration. However, the people of Eastern Turkey are different from the Turkish people in general, especially in simplicity and immaturity. The authorities are supposed to judge their abilities and then to see their needs according to their abilities.

In terms of departmental divisions, the Medresetü'z-Zehra would be divided into specialty branches following the division of labor. Each department would concentrate on a specific area to provide efficiency in each field. However, each branch would be interconnected with all fields through including one course from each field among the common required courses, which would be additional to the specialized courses (Nursi, 2002). These common courses would especially include the religious disciplines, which comprised the core of Medresetü'z-Zehra. Specialists would be expected to be able to grasp the spiritual wisdoms of his field together with a detailed mastery of the technical aspects of the field. Through the division of labour, each student had to share their studies with others in order to derive mutual benefit. The students had to know how each branch of knowledge is related to one another. Allocation of students to divisions would depend on determining the nature and competencies of the students. Otherwise, a noble field might get spoiled when incompetent students are appointed to it (Nursi, 1996). Moreover, according to Nursi (Nursi, 1996), only the specialists in a branch should have the right to comment on that field. In this way, he emphasized the need for specialization in areas for which the students have an aptitude. In addition to their specialized areas, students would only be allowed to study further subjects which complement it.

Although different branches of Medresetü'z-Zehra required specialization in different fields, members of each branch would sometimes have to get together to exchange their views through debates or discussions. In this way, the students would benefit from the ideas of each other, and a scholarly and scientific mentality would be developed among the students. The students specializing in different fields would have to communicate with others through participating in debates (Canan, 1994). This coming together of students from different faculties would be similar to the seminars, conference, and workshops practiced today among the higher academicians at both the national or international levels. Debates were to serve the most important function of Medresetü'z-Zehra, bringing together students and staff from the different religious and positive science specializations to share their views and studies, thereby integrating their fields. According to Nursi, the general thought inspired during the debates through the exchange of thoughts, would be like some sort of spiritual master who would sow the seed of life among the students and guide them to progress and reform, starting their student days (Kürdi, 1909). One of the reasons for the decline of medrese was the lack of employment prospects for the graduates of medrese. Medrese had lost its consideration as time passed because of unsatisfactory spiritual and financial support of the students and the teachers. Moreover, the medrese diploma became less acceptable than the mekteb diploma, making it difficult for graduates of medrese to find jobs (Cânan, 1994). Nursi complained that all the intelligent students went to mekteb while wealthy teachers did not consider the salary of medrese (Nursi, 2002). To solve this problem, the status of Medresetü'z-Zehra, including its examinations, would be officially equivalent to that of mekteb, to make it easier for the students to find jobs (Nursi, 2002).

Initially, Nursi thought that medrese would be in the vicinity of tribal dwellings, and the students would be the children of the tribes. Consequently, he proposed Medresetü'z-Zehra to be established in Bitlis, having two branches in Van to the east of Bitlis and Diyarbekir to the west. His narrow focus on the problems of Eastern Turkey later had to give way to a much wider perspective with the spread of the secular schools after the Tanzimat. Following the escalating problems, his concept grew to become a search for continental solutions, including the other Islamic countries. Hence Nursi proposed for an Islamic University to be founded in Asia because Ezher had already been in Africa. Towards the end of the Ottoman State, increasing problems arising from the schemes and designs of European imperialists on Islamic world, made his concept to embrace the entire Muslim world. Thus Eastern Anatolian students would benefit from this medrese more and their knowledge would be broadened through contact and interaction with students from other parts of the Muslim world, including Arabia, India, Iran, Caucasia, Turkistan, and Kurdistan etc.

Medresetü'z-Zehra was supposed to be an official foundation of the State, although it would be equivalent to the official high schools and its examination rules are similar to theirs. It was planned officially to be a private foundation. Initially, it would be supported by the government financially and administratively, especially regarding examinations and certification. Later, it would be permanently run as a private foundation. All medreses should unite under the Medresetü'zZehra, which would then pool together all the financial support. This would help to let resources flow into this pool by way of unifying the medreses. Since medreses are usually supported by private foundations, this would continue to support the most important educational institution financially with the sense of nation-love and enthusiasm. Zekât was expected to be another source. After some time, Medresetü'z-Zehra would attract for itself some zekât funds surely by giving a good 
service for Islam and humanity at large. Even a small portion of the zekât funds would be enough to cater for the needs of the institution. Beside zekâts, people giving charity by way of vows and alms, which are the national donations of Islam for beneficial establishments, would also turn their attentions to Medresetü'z-Zehra which would be a combination of medrese, mekteb, and tekke.

\section{Conclusion}

Focusing on educating individuals as means effecting social change has been questioned by some scholars. The fact that educating all individuals in society brings about fundamental changes, however, is indisputable. In line with this spirit, Nursi's education style, which focus on individuals, succeeded influence the society in a fundamental way. One reason behind the success of Nursi's individual education in changing society is the inculcation of social and universal holistic education to the individuals. This holistic education instructs the individuals how a society should have an ideal thought and life style. It accepts all members of society as constituents of its body. In contrast, the education system of the government which focused only on social education neglected the individuals. The individuals, who were considered of minor importance, became easy prey to the extreme groups such as the Darwinists, atheists, materialists, and communists. Others reacted to those extreme groups by following radical nationalists and Islamists or Sufi orders. This inevitably resulted in social clashes. Nursi's education system that directed towards individuals succeeded in uniting these opposed groups under the same roof by moderating their ideas with rational religious concepts.

\section{References}

al-Qur'an

Açıkgenç, A. (1995). An Evaluation of The Risale-I Nur From The Point Of View Of Knowledge And The Categorization Of Knowledge. Paper presented at the The reconstruction of islamic thought in the twentieth century and bediüzzaman Said Nursi, Third International Symposium on Bediüzzaman Said Nursi.

Akgündüz, A. (1993). A Genius They Tried to Misrepresent. Paper presented at the The ideas of Bediüzzaman Said Nursi in the thirtieth year since his death and their place in Islamic thought, First International Panel on Bediüzzaman Said Nursi.

Akgündüz, A. (1997). Belgeler Gerçekleri Konuşuyor (Vol. 1-5). Istanbul: Osmanlı Araştırmaları Vakfı.

Akgündüz, A. (1999). Bilinmeyen Osmanlı. Istanbul: OSAV.

Al-Kettani, A. (1995). Jihad in Bediuzzaman's Thought. Paper presented at the The Reconstruction of Islamic Thought in the Twentieth Century and Bediuzzaman Sa'id Nursi, Third International Symposium on Bediuzzaman Sa'id Nursi.

Alparslan, U. (1999). Bir Model Olarak Medresetüzzehra Projesi. 12-21.

Awang, R., Yusoff, K., Ebrahimi, M., Yilmaz, O. (2015). A Challenge from Teaching to Social Movement: Bediüzzaman Said Nursi's Struggles for Modification in Turkey. Mediterranean Journal of Social Sciences. Vol. 6 No. 6 S1. Pp: 444-451. DOI: 10.5901/mjss.2015.v6n6s1p444

Badıllı, A. (2005). The importance of Medresetü'z-Zehra, Med-Zehra Vakfı, Urfa. Interview.

Bolay, S. H. (1995). Bediuzzaman's View of Philosophy. Paper presented at the The Reconstruction of Islamic Thought in the Twentieth Century and Bediuzzaman Sa'id Nursi, Third International Symposium on Bediuzzaman Sa'id Nursi, Istanbul.

Cânan, İ. (1994). İslam Aleminin Ana Meselelerine Bediüzzaman'dan Çözümler. .

Kırkıncı, M. (2004). Hayatım-Hatıralarım, Mehmed Kırkıncı. Istanbul: Zafer Yayınları.

Kürdi, B S. (1909). "Bediüzzaman-I Kürdi'nin Fihriste-I Makasıdı (Index of the Purpose of Bediüzzaman-I Kürdi)." Volkan Gazetesi (Volkan Gazette).

Light, G. T. (2002). Neither can Russia continue without religion. International Magazine, April (Nur The Light), 9-15.

Michel, T. (2005). Said Nursi's Views on Muslim-Christian Understanding. Istanbul: Söz Basım Yayın.

Mürsel, S. (1995). Bediüzzaman Said Nursi ve Devlet Felsefesi. Istanbul: Yeni Asya Yayınları.

Nursi, B. S. (1996). Muhakemat. Istanbul: Sözler Yayınevi.

Nursi, B. S. (1997). Letters (Second Revised ed.). Istanbul: Sözler Ofset A.S.

Nursi, B. S. (1998). The words. Istanbul: Sözler Neşriyat A.S.

Nursi, B. S. (2002). Munazarat (The Debates). Istanbul: Sözler Yayınevi Publication.

Nursi, B. S. (2003). Divan-ı Harb-i Örfi. Istanbul: Sözler Yayınevi Publication.

Öke, M. K. (1993). Sa'id Nursi and Britain's Psychological Warfare Against Ottoman Turkey, 1909-22. Paper presented at the First International Panel on Bediuzzaman Sa'id Nursi. The Ideas of Bediuzzaman Sa'id Nursi in the Thirtieth Year since His Death and Their Place in Islamic Thought.

Öke, M. K. (1995). Islamic Knowledge in the Information Age and Bediuzzaman. Paper presented at the The Reconstruction of Islamic Thought in the Twentieth Century and Bediuzzaman Sa'id Nursi, Third International Symposium on Bediuzzaman Sa'id Nursi.

Şen, S. Z. (1985). Bediüzzaman'da Cemiyet Görüşü. (Master Thesis), Uludağ University, Bursa.

Vahide, Şükran. (1995). "Jihad in the Modern Age: Bediuzzaman Sa'id Nursi's Interpretation of Jihad." In The Reconstruction of Islamic Thought in the Twentieth Century and Bediuzzaman Sa'id Nursi, Third International Symposium on Bediuzzaman Sa'id Nursi, 
Vol. 1. Sözler Publications.

Yetim, S. (1998). Bediuzzaman Sa'id Nursi'nin Eğitim ve Irş̧ad Metodları. (Master Thesis), Harran University, Turkey.

Yusoff, K., Yilmaz, O., Ebrahimi, M. (2013). Transition in Turkey: An Overview of Bediüzzaman Said Nursi, His Life and Works for Medresetü'z-Zehra. International Journal of West Asian Studies. Vol. 5 No. 2. Pp: 67-77. DOI: 10.5895/ijwas.2013.11 